\title{
Audit Committee and Earnings Management of Listed Deposit Money Banks in Nigeria
}

\author{
Ibrahim Mallam Fali ${ }^{*} \quad$ Alkasim Aminu ${ }^{2} \quad$ Udoh Ekufre Macauley ${ }^{3}$ Onipe Adabenege Yahaya, $\mathrm{PhD}^{3}$ \\ 1.Department of Accounting, University of Calabar \\ 2.Department of Accounting, Umaru Musa Yar'adua University, Katsina \\ 3.Department of Accounting and Management, Nigerian Defence Academy Nigeria
}

\begin{abstract}
There exists divergence of opinions in the literature on the impact of audit committee on earnings management. The mixed opinions make the direction of the impact ambiguous. This study therefore investigates the impact of audit committee on Earnings Management of listed deposit money banks in Nigeria. Earnings management was measured using Chang, Yat-sen, Shen and Fang (2008) Discretionary Loan Loss Provision Model. The study adopts correlational research design of which secondary data were extracted from the 13 sampled deposit money banks listed on the Nigerian Stock Exchange for the period 2008-2017. The study employed Random Effects Model (REM) to analyze the data. The results revealed that audit committee financial expertise and audit committee busyness have negative significant impact on earnings management, audit committee tenure has a negative insignificant impact on earnings management. Audit committee meeting and audit committee share ownership have positive insignificant impact on earnings management. The study concludes that audit committee expertise and busyness improve the quality of financial report of deposit money banks in Nigeria. The study recommends among others that the board should ensure that members with financial expertise are appointed into audit committee as it enhances the earnings management of the banks. The inclusion of more directors with multiple directors on the audit committee as their wealth of experience helps in reducing earnings management thus improving the earnings management of the banks.
\end{abstract}

Keywords: audit committee, earnings management, audit committee busyness, financial expertise, share ownership

meeting, tenure,

DOI: $10.7176 /$ RJFA/10-16-13

Publication date: August $31^{\text {st }} 2019$

\section{Introduction}

Audit Committee (AC) is an essential element of corporate governance that can enhance the quality of financial reporting through an open and candid communication of financial and non-financial information and a good working relationship with a company's board of directors, internal auditors and external auditors.

Undeniably, the existence of an appropriately constituted audit committee is now a necessity for all listed companies in the United Kingdom and United States of America and same in Nigeria (Sarbanes-Oxley Act, 2002; The UK Corporate Governance Code, 2010 and Nigeria SEC Code, 2011). In Nigeria, the creation and establishment of an audit committee is made mandatory by the Companies and Allied Matters Act (CAMA) of 2004. Section 359 (3) states that "The auditor shall in the case of a public company also make a report to an audit committee which shall be established by the public company". According to CAMA, Section 359 (4), the makeup of the audit committee shall consist of an equal number of directors and representatives of the shareholders of the company (subject to a maximum number of six members)".

The primary objective of financial reporting is to provide high-quality financial reporting information concerning economic entities, primarily financial in nature, useful for economic decision making in an organizational set up. Providing high quality financial reporting information is important because it will positively influence capital providers and other stakeholders in making investment, credit, and similar resources allocation decisions that will enhance the overall market efficiency. The accounting scandals of the early 2000 s, clearly demonstrate the importance of quality of financial reporting to investors and other stakeholders. However, the interpretation of quality of financial reporting remains problematic due to different financial reporting environments, regulations, procedures, and understandings. One good aspect of quality issues in financial accounting is from the International Accounting Standard Board (IASB), which identifies six (6) qualitative characteristics of both fundamental and enhancing characteristics viewed as desirable for the fulfillment of their fundamental objective of communicating decision-useful measurements: relevance, faithful representation, understandability, comparability, verifiability, and timeliness.

Despite the 2003 and subsequent revised code of corporate governance issued by Securities and Exchange Commission (SEC) that has been enacted to establish effective audit committees with the required quality and characteristics in the Public Companies in Nigeria as well as clear duties and responsibilities for effective financial reporting and accountability, there have been reported cases of Corporate failures in Nigeria that have raised great 
concern in the development of corporate businesses. In the banking sector alone, 45 banks were liquidated in between 1994 to 2006, while in 2007, 14 banks were liquidated. In 2009, the Central Bank of Nigeria (CBN) sacked the managing directors and Chief Executives Officers (CEOs) of five commercial banks along with their executive directors. On October 2, 2009, the Central Bank of Nigeria announced an additional sack of three bank CEOs and their respective board of directors all due to excessive high level of non-performing loans, which was attributable to poor corporate governance mechanism, lack of credit administration process, the unethical practices by the management and the bank credit risk management practices (Economic Confidential, 2009). As of these and other scandals recorded in Nigeria in recent times, international organizations, financial regulatory authorities and academicians became much concerned about corporate governance issues in Nigeria ( Madawaki \& Noor, 2013). These issues brought doubt in the minds of shareholders on the credibility and reliability of earnings management (Bala \& Gugong, 2015).

It is considered as failures of audit committee in discharging their duties and functions accordingly and that impressed researchers to consider it of paramount importance to examine the impact of audit committee on earnings management but documented mixed results. For example, Eriabie et al. (2016), Muhammad, Ayoib and Noor (2016) and Adeyemo, Eriebie, Adetiloye and Ben-Caleb (2015) reported positive relationships. While others found negative associations (Koholga, Babangida \& Monica, 2015). Other researchers reported weak relationship (Madawaki \& Noor, 2013). More so, in Nigeria, studies in this area mostly have ignored the instance of audit committee busyness variable which means the issue of holding multiple directorships not only remains a major concern for governance regulators but also remains a focus of research attention. Additionally, the time period covered by some of the previous studies leaves a gap to fill. The works of Mbobo and Adebimpe (2016) for instance, covered the period from 2006 to 2013. Sylvester et al. (2016) covered the period of 2006 to 2012 and Onyabe, Okpanachi, Nyor, Yahaya, and Ahmed (2018), covered the period of 2007 to 2016 and we are expanding it to year 2017.

Therefore, this study is empirically investigates the impact of audit committee on Earnings Management of listed money deposit banks in Nigeria and hypothesized that audit committee characteristics does not have significant impact on Earnings Management of listed Nigerian deposit money banks. The hypotheses for this study are stated in null forms as follows:

$\mathrm{H}_{01}$ : Audit committee financial expertise has no significance effect on financial reporting quality of listed deposit money banks in Nigeria.

$\mathrm{H}_{02}$ : Audit committee meeting has no significance effect on financial reporting quality of listed deposit money banks in Nigeria.

$\mathrm{H}_{03}$ : Audit committee tenure has no significance effect on financial reporting quality of listed deposit money banks in Nigeria.

$\mathrm{H}_{04}$ : Audit committee share ownership has no significance effect on financial reporting quality of listed deposit money deposit banks in Nigeria.

$\mathrm{H}_{05}$ : Audit committee busyness has no significance effect on financial reporting quality of listed deposit money banks in Nigeria.

The study rests on its expected practical implications. On the practical implication, the study will produce reliable empirical evidence that will encourage Nigerian Banks to be attuned with the global paradigm shift from tangible resources and with audit committee characteristics, it is anticipated that this will enhance the competitive states of Nigerian Banks in the global market where auditing has been made compulsory for corporate entities. The study could also be beneficial in providing them with (corporate management) useful insight as they seek to take advantage of corporate reporting in increasing their productivity, profitability, investment and business growth. This study is also contributed to the literature on audit committee and earnings management and regulators of Nigeria capital market in increasing the effectiveness of the audit committee listing rules. The study covers the period of ten (10) years from 2008 to 2017. The population of the study is entire listed Nigerian deposit money banks. To accomplish this study, the paper is divided into five sections namely: section one is the Introduction, section two takes up the literature review, section three presents the methodology, section four deals with results and discussions and section five conclude the study.

\section{Literature Review}

The audit committee performs an important role in the financial monitoring of a firm. First, according to Blue Ribbon Committee 1999; Bill 2006, audit committee members maintain responsibility for oversight over accounting policies and judgments, as well as the quality of the overall financial statements. Furthermore, the audit committee is normally accountable for selecting outside auditors, and meeting with financial managers to measure whether they are acting in the firm's best interest (Klein 2002b). DeFond et al. (2005) suggests that these responsibilities often require notable accounting complexity in that they involve evaluating the reasonableness of complex financial matters such as the company's accounting reserves, and management's handling of proposed audit adjustments suggested by the external auditors. The conceptual framework is presented in figure 1 


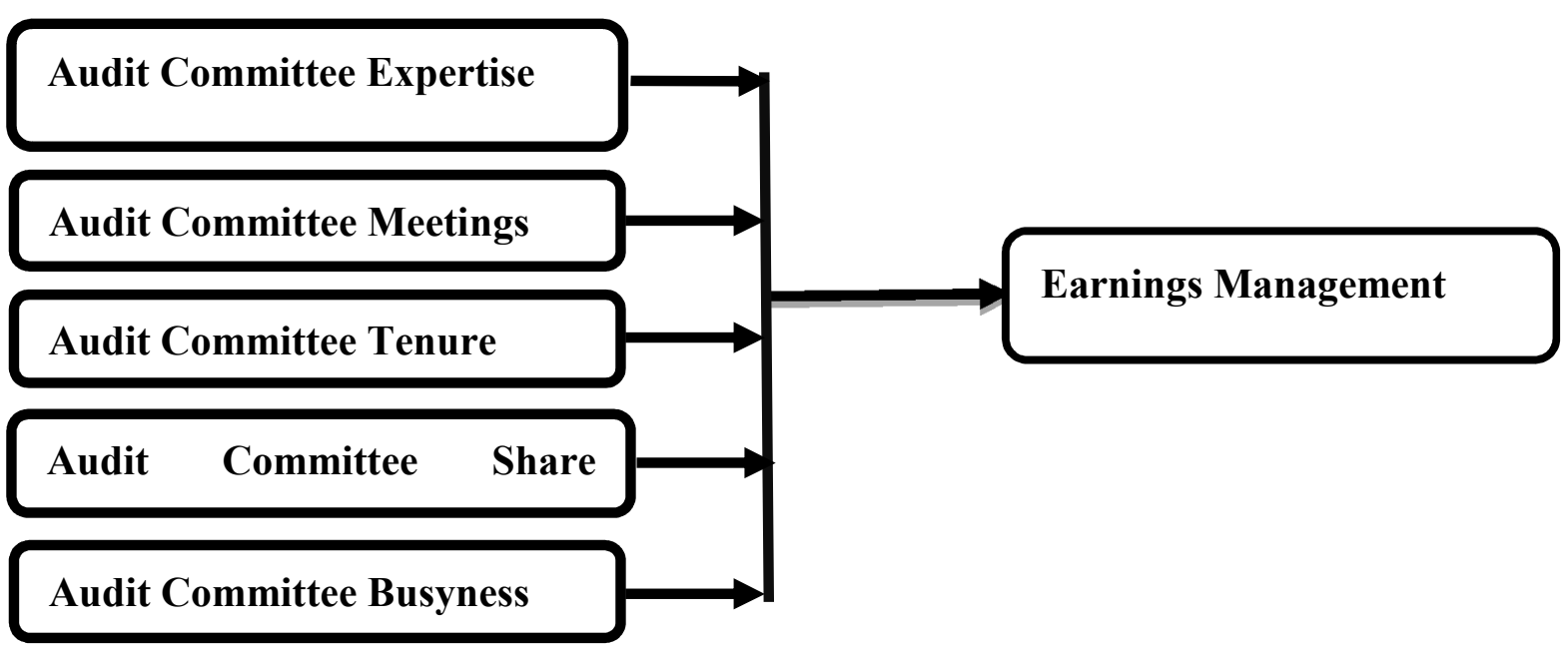

Figure 1: Conceptual Framework

(Umobong \& Ibanichuka, 2017)

There are different definitions of quality of financial reporting. Some of the seven qualitative characteristics quality issues in financial accounting viewed as desirable for the fulfillment of their fundamental objective of communicating decision-useful measurements include relevance, understandability, reliability, completeness, objectivity, comparability, and timeliness (Honu \& Gajevszky, 2014). In financial accounting, earnings management may be judged from a number of proxies such as earnings persistence, predictability of future performance, earnings variability, and relation between cash, accruals and income (Bushman \& Piotroski, 2006). $\mathrm{Li}$, (2010) found that accounting standards are the major determinant of earnings management among other institutional factors. In order to have high quality financial reporting the accounting standards must first be of high quality.

Van Beest, Braam and Boelens (2009) on their part posited that since different user groups will have dissimilar preferences, perceived quality will deviate among constituents. In addition, the users within a user group may also perceive the usefulness of similar information differently given its context. As a result of this context and user-specificity, measuring quality directly seems problematic. Consequently, many researchers measure the quality of financial reporting indirectly by focusing on attributes that are believed to influence quality of financial reports, such as earnings management, financial restatements, and timeliness (Barth et al., 2008).

In 2002, the International Accounting Standards Board (IASB) and the Financial Accounting Standards Board (FASB) showed their commitment towards developing a common set of high-quality accounting standards, which could be used worldwide. As a consequence of the joint project to converge the more principles-based International Financial Reporting Standard (IFRS) and the more rules-based US General Accepted Accounting Practice (GAAP), both boards agreed to develop new joint conceptual framework, which includes the objectives of financial reporting and the underlying qualitative characteristics on which accounting standards ought to be based. In October 2010, the FASB and the IASB therefore published an exposure draft of an improved Conceptual Framework for Financial Reporting (IASB, 2010). Some of the measure contained in the conceptual framework included relevance, faithful representation, verifiability, understandability, comparability and timeliness.

Another major characteristic of audit committees is expertise. There are three main classes of expertise of audit committees: outside directorship (Beasley 1996; Vafeas 2005); financial and accounting expertise (Abbott et al. 2004; Krishnan and Visvanathan 2008); and industry expertise (Cohen et al. 2014).

Onyabe, Okpanachi, Nyor, Yahaya, and Ahmed (2018) in their study discovered and concluded that audit committee expertise has an insignificant impact the Financial Reporting Quality. Kusnadi, Leong Suwardy, and Wang (2014) opined that financial expertise improve the Financial Reporting Quality through their professional knowledge. The appointment of audit committee members with financial and accounting expertise can lead to significant positive market reaction (Davidson III et al. 2004; DeFond et al. 2005). For example, DeFond et al. (2005) discover positive abnormal returns when a financial and accounting expert is assigned to the audit committee. It is expected that the audit committee members' skills play a vital role in the way that they carry out their duties (Kalbers and Fogarty 1993). Knapp (1987) found that auditors might reduce the audit committee's oversight role if they believe that the audit committee does not have the necessary knowledge to understand technical auditing and financial reporting matters.

Stewart and Munro (2007) concentrated on the results of the number of times of meetings of the audit committee. They determined that the presence of an audit committee, the number of its meetings and the auditor's attendance for such meetings decreases audit risks, and that the external auditor accepts that the presence of an 
audit committee is a vital element in reducing substantial risks of auditing. They further ascertained that reducing such risks is also affected by frequent meetings of the audit committee and auditor's attendance of such meetings. Osarumwense and Aderemi (2016) suggest that the frequency of meetings affects the quality of financial reporting. Zhang and Zhou (2007) used the number of meetings to measure whether the frequency affects quality of financial reporting. Inactive audit committees with less number of meetings were found to be unlikely to supervise management effectively. The study further discovered that fraudulent firms with earnings misstatements have fewer audit committee meetings than non-fraud firms. Ruzaidah and Takiah (2004) discover that good reporting companies meet more often than the poor reporting companies. The more frequent audit committees meet, the better the quality of financial reporting because they can oversee the management activities quickly and efficiently in the meeting (Ruzaidah \& Takiah, 2004). However, Onyabe, Okpanachi, Nyor, Yahaya, and Ahmed (2018) examines the effect audit committee meeting and expertise on Earnings Management of listed deposit money banks (DMB's) in Nigeria and discovered that the numbers of audit committee meeting does not affect Financial Reporting Quality.

Page and Spira (2005) examine the tenure of audit committee directors on the board which is another important element in ascertaining the effectiveness of audit committees in carrying out their monitoring function. Vafeas (2005) disagrees that longer board service might compromise audit committee directors' independence by bringing directors and management closer resulting in directors 'befriending' management. Vafeas (2005) records a positive association between the mean tenure of audit committee members and poor earning quality measure, showing an inverse relationship between the average tenure and earnings quality. Boone, Khurana and Raman (2008) find some evidence for a non-linear relationship between auditor committee tenure of Big 5 audits and financial reporting credibility by using the ex-ante equity risk premium. Their results show that the equity risk premium decreases in the early years of an auditor-client relationship and increases with each additional year past 13 years of auditor tenure. Onyabe, Okpanachi, Nyor, Yahaya \& Ahmed (2018), carry out study on Effect of Audit Committee Tenure on Financial Reporting Quality of Listed Deposit Money Banks in Nigeria confirmed that audit committee tenure does not influence on earnings management.

Audit Committee share ownership represents the audit committee member proportion of shareholdings in the company. The effectiveness of audit committee members' share ownership on the monitoring of the financial reporting process has been recorded by many studies. The empirical facts show there is a potential relationship between share ownership and the effectiveness of the financial reporting process. Forker, 1992; Lavelle, 2002, argued that independence of audit committee members with high portion of shareholdings can be questioned as they may seek greater levels of control in the operations of the firm in order to protect their investments. Carcello and Neal (2003) found that in firms where audit committee members' share ownership was high, audit committee members may apply undue power to discharge an external auditor after issuing a going concern report to protect their vested interest.

Alternatively, it has been implied that share ownership can result in greater alertness by audit committee members, as they have more of a stake in ensuring the company carries out its functions efficiently (Jensen, 1989; Shivdasani, 1993). Thus, a high shareholding by audit committee members (as NEDs) can actually help improve the financial reporting process by motivating them to monitor more effectively. Directors that have more shareholding will be motivated to monitor and instigate management reporting (Jensen, 1993). Jensen (1993) argues this incentive is usually higher for corporate directors compared to short-term investors as they probably have a long-term orientation.

The issue of holding multiple directorships not only remains a significant interest for governance regulators but also remains a focus of research attention, stretching from the empirical evidence on the determinants of multiple directorships (O’Sullivan, 2005; O'Sullivan, 2009) to the effect of such directors on various financial matters (Fich and Shivdasani, 2006). A common opinion among policy advocates is that serving on many boards can result in overworked directors that may not be effective monitors on any board. In the UK, the Combined Code (2003) recommends that 'executives should be discouraged from holding more than one non-executive directorship in another listed company'. Fama and Jenson (1983) maintain that the reputation of directors as monitoring expert are certainly related with additional directorships, thus showing that busy directors may be more able directors than their counterparts. A number of studies show the importance connected with holding additional directorships (Shivdasani, 1993; Ferris et al., 2003; Carcello et al., 2002b; Bedard et al., 2004; Yang and Krishnan, 2005).

This study has adopted the agency theory in explaining the relationship between audit committee characteristics and earnings management of listed deposit money banks in Nigeria. Audit committees act for the concerns of shareholders and therefore a suitable functioning audit committee has a major function in preventing agency conflicts that may arise between shareholders and management. According to agency theory, earnings management will be realized when conflicting interests are solved in good time a role that can be effectively played by the audit committees. 


\section{Methodology}

For the purpose of study, correlational research design was adopted. The population of this study covers all the fourteen (14) banks listed on the floor of Nigerian Stock Exchange as at December 2017. Census sampling techniques was adopted and Sky Bank Nig. Plc was dropped out due to the inability to publish their annual reports and accounts for 2016 and 2017 and subsequently, the bank was taking over by Polaris bank in last quarter of 2018 . Tables 1 contain the names of banks that make up the population and sample size of the study.

Table 1

List of listed Banks in the Nigerian Stock Exchange as at 2017

\begin{tabular}{llcccc} 
S/NO & Deposit Money Banks in Nigeria & Population & $\begin{array}{c}\text { Sample } \\
\text { Size }\end{array}$ & $\begin{array}{c}\text { Year of } \\
\text { Incorporation }\end{array}$ & $\begin{array}{c}\text { Year of Listing } \\
\text { on NSE }\end{array}$ \\
\hline $\mathbf{1}$ & Access Bank Nig. Plc & $\sqrt{ }$ & $\sqrt{ }$ & 1989 & 1998 \\
$\mathbf{2}$ & Diamond Bank Nig. Plc & $\sqrt{ }$ & $\sqrt{ }$ & 1990 & 2005 \\
$\mathbf{3}$ & Fidelity Bank Nig. Plc & $\sqrt{ }$ & $\sqrt{ }$ & 1987 & 1999 \\
$\mathbf{4}$ & First Bank Holding & $\sqrt{ }$ & $\sqrt{ }$ & 1969 & 1971 \\
$\mathbf{5}$ & First City Monument Bank Nig. Plc & $\sqrt{ }$ & $\sqrt{ }$ & 1982 & 2004 \\
$\mathbf{6}$ & Guaranty Trust Bank Nig. Plc & $\sqrt{ }$ & $\sqrt{ }$ & 1990 & 1996 \\
$\mathbf{7}$ & Sky Bank Nig. Plc & $\sqrt{ }$ & & 1990 & 2006 \\
$\mathbf{8}$ & Stanbic IBTC Bank Nig. Limited & $\sqrt{ }$ & $\sqrt{ }$ & 1999 & 2005 \\
$\mathbf{9}$ & Sterling Bank Nig. Plc & $\sqrt{ }$ & $\sqrt{ }$ & 1969 & 1992 \\
$\mathbf{1 0}$ & Union Bank of Nig. Plc & $\sqrt{ }$ & $\sqrt{ }$ & 1968 & 1971 \\
$\mathbf{1 1}$ & United Bank for Africa Nig. Plc & $\sqrt{ }$ & $\sqrt{ }$ & 1967 & 1971 \\
$\mathbf{1 2}$ & Unity Bank Nig. Plc & $\sqrt{ }$ & $\sqrt{ }$ & 1987 & 2005 \\
$\mathbf{1 3}$ & Wema Bank Nig. Plc & $\sqrt{ }$ & $\sqrt{ }$ & 1945 & 1991 \\
$\mathbf{1 4}$ & Zenith Bank Nig. Plc & $\sqrt{ }$ & $\sqrt{ }$ & 1990 & 2004 \\
\hline
\end{tabular}

Source: Compiled from NSE Fact Book, 2017.

The study will make use of multiple correlation model to determine the impact of audit committee characteristics on earnings management of listed deposit money banks in Nigeria. In line with the research paradigm underpinning this study and consistent with the objectives of this study, Ordinary Least Square (OLS) model was employed as follows:

$E M_{i t}=\beta 0+\beta 1 A C F E X P_{i t}+\beta 2 A C M E E T_{i t}+\beta 3 A C T E_{i t}+\beta 4 A C S O W_{i t}+\beta 5 B U S Y_{i t}+e_{i t}$

Where:

$\mathrm{EM}=$ measured by Discretionary loan loss provision

ACFEXP = Audit Committee Expertise

ACMEET $=$ Audit Committee Meetings

ACTEN = Audit Committee Tenure

ACSOW = Audit Committee Share Ownership

ACBUSY = Audit Committee Busyness

$\varepsilon_{\mathrm{it}}=$ Error term

$\beta 0=$ is the intercept

$\beta 1-\beta 5=$ are the parameters to be estimated in the equation

$\mathrm{EM}=$ earnings management, measured using the residuals from discretionary loan loss provision model based by Chang, Shen and Fang (2008) used by Farouk and Isa (2018) etc.

The choice of the model of discretionary loan loss provision is that it was specifically built for financial sector (Chang et al. 2008). The model is shown below:

$\mathrm{LLP} / \mathrm{Ta}_{\mathrm{t}-1 \mathrm{it}}=\alpha_{0} 1 / \mathrm{TA}_{\mathrm{it}-1}+\alpha_{1} \mathrm{LCO}_{\mathrm{it}} / \mathrm{TA}_{\mathrm{it}-1}+\alpha_{2} \mathrm{BBAL}_{\mathrm{it}} / \mathrm{TA}_{\mathrm{it}-1}+\varepsilon_{\mathrm{it}}$

Where

$\operatorname{DLLP}_{i t}=\varepsilon_{\text {it }}=\operatorname{LLP}_{\text {it }-}\left(\alpha_{0} 1 / \mathrm{TA}_{\text {it }-1}+\alpha_{1} \mathrm{LCO}_{\mathrm{it}} / \mathrm{TA}_{\mathrm{it}-1}+\alpha_{2} \mathrm{BBAL}_{\mathrm{it}} / \mathrm{TA}_{\mathrm{it}-1}\right)$

Where: $L L P=$ Loan Loss Provision for firm $\mathrm{i}$ at time $\mathrm{t}$.

$L C O=$ the Loan Charge-offs for firm i at time t.

$B B A L=$ the beginning balance of LLP for firm $\mathrm{i}$ at time $\mathrm{t}$.

$T A=$ the beginning total asset of firm $\mathrm{i}$ at time $\mathrm{t}$.

$\mathrm{e}=$ the error term

$=$ the intercept

This variables used in this study are the dependent variable which is earnings management and the independent uses a number of variables to proxy for audit committee characteristics. (i.e. Meetings, financial expertise, tenure, effectiveness, busyness and share ownership) the main dependent and independent variables of interest and their measurement constructs are presented in table 2 below. 
Table 2

Operationalization of variables

\begin{tabular}{|c|c|c|c|c|c|}
\hline $\mathbf{S} / \mathbf{N}$ & VARIABLES & DEFINITION & TYPE & MEASUREMENT & AUTHORS \\
\hline 1 & FRQ & $\begin{array}{l}\text { Earnings } \\
\text { Management }\end{array}$ & Dependent & $\begin{array}{l}\text { Discretionary loan } \\
\text { provision }\end{array}$ & $\begin{array}{l}\text { Chang } \\
\text { al.(2009) }\end{array}$ \\
\hline 2 & ACFEXP & $\begin{array}{l}\text { Audit Committee } \\
\text { Financial } \\
\text { Expertise }\end{array}$ & Independent & $\begin{array}{l}\text { Proportion of audit committee } \\
\text { members with accounting or } \\
\text { financial qualification }\end{array}$ & $\begin{array}{l}\text { Madawaki \& } \\
\text { Amran (2017) }\end{array}$ \\
\hline 3 & ACMEET & $\begin{array}{l}\text { Audit Committee } \\
\text { Meetings }\end{array}$ & Independent & $\begin{array}{l}\text { Number of times the audit } \\
\text { committee meetings held } \\
\text { during the year }\end{array}$ & $\begin{array}{l}\text { Madawaki \& } \quad \text { Amran (2017) }\end{array}$ \\
\hline 4 & ACTE & $\begin{array}{l}\text { Audit Committee } \\
\text { Tenure }\end{array}$ & Independent & $\begin{array}{l}\text { Audit committee members } \\
\text { with above } 3 \text { years as a } \\
\text { member }\end{array}$ & $\begin{array}{l}\text { Ghafran } \\
\text { (2013) }\end{array}$ \\
\hline 5 & ACSOW & $\begin{array}{l}\text { Audit Committee } \\
\text { Share Ownership }\end{array}$ & Independent & $\begin{array}{l}\text { Proportional share of non- } \\
\text { executive } \\
\text { members on audit committee } \\
\text { /total company shareholdings }\end{array}$ & $\begin{array}{l}\text { Kibiya, Ahmad } \\
\&\end{array}$ \\
\hline 6 & ACBUSY & $\begin{array}{l}\text { Audit Committee } \\
\text { Busyness }\end{array}$ & Independent & $\begin{array}{l}\text { members with more than one } \\
\text { directorship }\end{array}$ & $\begin{array}{l}\text { Ghafran } \\
(2013)\end{array}$ \\
\hline
\end{tabular}

Source: Compiled from literature

The study used secondary data only to examine the impact of audit committee characteristics on earnings management of listed deposit money banks in Nigeria. In this regard, the sources of data for the study will be the Nigerian Stock Exchange (NSE) Fact Books for 2008 - 2017 and the annual reports and accounts of the banks for all the years covered by the study. Ordinary least square regression was adopted to empirically run the regress using STATA as tool of analysis. STATA was used because the study extracts the residual with it. The study uses correlation in order to determine the relationships between the variables of the study. Regression is employed because the study wants to determine the cause and effect of each variable. And finally, the study conducted robustness tests like, Hausman test and Heteroscedasticity test and Multi-collinearity test in order to improve the validity of statistical inferences. To ensure that the data for this is fit for the model, the study will conducts data normality test as well as a test for multi-collinearity and heteroscedasticity among explanatory variables. Other test will include: Diagnostic tests and test of hypotheses.

\section{Results and Discussion}

The summary statistics of the explained and the explanatory variables are presented in Table 3 where minimum, maximum, mean and standard deviation of the data collected for the variables in the study are described.

Table 3

Descriptive Statistics of the Variables

\begin{tabular}{llllll}
\hline Variables & OBS & MEAN & STD DEV & MIN & MAX \\
\hline FRQ & 130 & .03 & 03 & -.001 & .20 \\
ACFEXP & 130 & .27 & .14 & .17 & 0.67 \\
ACMEET & 130 & 4.3 & 1.20 & 1 & 7 \\
ACTE & 130 & .53 & .50 & 0 & 1 \\
ACSOW & 130 & .04 & .12 & 0 & .24 \\
ACBUSY & 130 & .71 & .45 & 0 & 1 \\
\hline
\end{tabular}

Source: Descriptive Statistics Result using STATA 13

Table 3 shows the detail account of the descriptive statistics for the explained and explanatory variables. Discretionary loan loss provision which is the dependent variable of the study has a minimum value of -..001 and a maximum value of .20 . The average value of the DLLP is 03 with standard deviation of 03 which suggests that there is a low disparity in the way in which the sampled banks managed their earnings.

The table also shows that the mean value for audit committee expertise is .271 and the standard deviation is .14. This shows that on average, $27.1 \%$ of the audit committee members are financial expertise and these pattern is similar in the sampled banks evidence from the standard deviation value. The least and the highest value is 0.17 and 0.67 . The summary statistics from the table with respect to audit committee meeting, the average value of ACMEET is 4.3 with a standard deviation of 1.20 . The average of 4.3 signifies on average the audit committee holds meetings for more than 4 times. The standard deviation shows that there is low variation of the variable from the mean. It further shows that the attendance to meeting across the sampled banks follows similar pattern. The table also indicates that the minimum and maximum values of the audit committee meeting are 1 and 7 respectively,

The result also indicates that Audit committee tenure (ACTE) has minimum and maximum value of 0 and 1 
respectively since it is a dichotomous variable. The average value of the audit tenure is 0.53 and a standard deviation of 0.50 . The average value is an indication that more than $53 \%$ of the audit committee members stays for three years and above in the committee. The standard deviation shows that there is a close cluster of the variables around the mean.

In addition, the audit committee share ownership shows an average value of .04 and a standard deviation of .12 indicating that there is a wide dispersion of the variable from the mean. The least value and the highest value of audit committee is 0 and .24

The table also indicates that audit committee busyness has a minimum of 0 and a maximum of 1 , on average .7076 which is $70.76 \%$. This suggest that on average more than $70 \%$ of the sampled deposit money banks in Nigeria hold more than one directorship. The standard deviation of .4565 also shows that this multiple directorship is a common practice among the sampled listed deposit money banks in Nigeria.

In this section, the results of normality of the data, multicollinearity test, heteroscedasticity test, hausman specification test, are presented and discussed, as shown in the table below as follows

The normality individual data was test using Sharpiro wilks test at 5\% level of significant. The results in the table 4 shows that DLLP, ACFEXP and ACSOW have significant p-value which suggest that the individual data is not normal distributed. Further the table shows that ACMEET, ACTE and ACBUSY are normal distributed evidence from their insignificant p-value.

Table 4

Normality test

\begin{tabular}{llllll}
\hline Variables & Obs & W & V & $\mathbf{Z}$ & Prob $>\mathbf{Z}$ \\
\hline DLLP & 130 & 0.76 & 24.46 & 7.19 & 0.00 \\
ACFEXP & 130 & 0.82 & 17.68 & 6.47 & 0.00 \\
ACMEET & 130 & 0.98 & 1.60 & 1.04 & 0.15 \\
ACTE & 130 & 0.99 & 0.05 & -6.87 & 1.00 \\
ACSOW & 130 & 0.67 & 34.34 & 7.95 & 0.00 \\
ACBUSY & 130 & 0.99 & 1.41 & 0.78 & 0.22 \\
\hline
\end{tabular}

Source: Sharpiro wilk test for normality result using STATA 13

\section{Multicollinearity Test}

Table 5

Multicollinearity test

\begin{tabular}{lll}
\hline Variable & VIF & 1/VIF \\
\hline ACFEXP & 1.09 & 0.91 \\
ACMEET & 1.04 & 0.96 \\
ACTE & 1.02 & 0.98 \\
ACSOW & 1.04 & 0.96 \\
ACBUSY & 1.04 & 0.96 \\
\hline MEAN VIF & 1.04 & \\
\hline
\end{tabular}

Source: VIF result using STATA 13

The classical assumption of OLS regression model assumes among others, that the error terms are normally distributed and independent (that is the error terms are uncorrelated); the explanatory variables are not perfectly correlated (absence of multicollinearity); and the variance of the error terms is constant (Homoskedastic). When these assumptions have not been met, the estimators are biased and cannot be used in drawing any inference. However, the results from Table 4.3 proved that there is no existence of excessive correlation among the independent variables, because the smallest tolerance value (TV) is 0.98 , while the highest variance inflation factor (VIF) is 1.04. The rule of thumb for the Tolerance Value is that any value of 0.1 and below and the VIF value of 10 and above imply the presence of multicollinearity in the estimates (Gujarati, 2004).

Heteroscedasticity test was carried out to check the homoscedasticity assumption of a regression model. To test for the existence of heteroscedasticity, this study uses the Breusch- Pagan or cook - Weisberg. The result reveals that chi2 is 37.54 and the prob $>\mathrm{chi}^{2}$ is 0.0000 which is significant at $1 \%$ level of significance. This shows that there is presence of heteroscedasticity.

Hausman specification test was conducted to choose the most appropriate model for the study. The result shows that at $5 \%$ level of significance, the chi2 is 10.65 and the prob $>$ chi2 2 is 0.0589 which is insignificant. This insignificant $p$-value shows that Hausman test favors random effect model. Further the study carried out Breusch and Pagan Lagrangian multiplier test for random effects to check if there is panel effect, that is, to choose between the random effect result and OLS regression. The result revealed a chi square of 70.72 and Prob $>$ chibar2 is 0.0000 indicating that there is a panel effect. Hence, the study interpreted the random effect model.

In this section, the regression results of audit committee attribute variables and earnings management are presented and analyzed. 
Table 6

Random effect Regression Model

\begin{tabular}{lllll}
\hline Variable & Coefficients & Std error & t-value & p-value \\
\hline ACFEXP & -.34 & .06 & -5.82 & 0.00 \\
ACMEET & .00 & .00 & 1.06 & 0.29 \\
ACTE & -.00 & .00 & -0.99 & 0.32 \\
ACSOW & .05 & .03 & 1.41 & 0.16 \\
ACBUSY & -.01 & .00 & -3.05 & 0.00 \\
CONSTANT & .01 & .01 & 1.25 & 0.21 \\
& & & & \\
R2 overall & 35.61 & & & \\
f-statistic & 64.79 & & & \\
p-value & 0.00 & & & \\
\hline
\end{tabular}

Source: Random effect model result using STATA 13

Table 6 presents random effect regression result selected for the study based on the hausman test. The regression result reveals that the independent variables, audit committee characteristic variables (audit committee financial expertise, audit committee meeting, audit committee tenure, audit committee busyness and audit committee shareholder ownership) are able to explain up to $35.61 \%$ of the variations in the earnings management of the sampled listed deposit money banks while the remaining percentage is explained by other factors not captured in the model. The F- statistics chi square is 64.79 with a p-value of 0.0000 which reveals that the model is fitted at $1 \%$ significant level.

The hypotheses of the study were tested from the regression result presented in Table 6

Hypotheses 1: audit committee expertise has no significance effect on earnings management of listed deposit money banks in Nigeria.

The result from table 6 shows that audit committee financial expertise has a significant negative impact on FRQ of listed deposit money banks in Nigeria as indicated by the coefficient of -.34 with P- value of 0.000 which is statistically significant at $1 \%$ level of significance. That is, audit committee expertise is significant in improving the Earnings Management of listed DMB's firms in Nigeria. Based on this, the study rejects the null hypotheses hypothesis one $\left(\mathrm{H}_{01}\right)$ which states that, audit committee financial expertise has no significance effect on Earnings Management of listed deposit money banks in Nigeria.

Hypotheses 2: audit committee meeting has no significance effect on earnings management of listed deposit money banks in Nigeria.

On the contrary, the results from the table shows that the audit committee meeting (ACMEET) has a positive impact on FRQ of listed DMB'S in Nigeria, from the coefficient of .00 which is not significant at any levels of significance ( $p$-value of 0.29). This suggests that audit committee meeting has no significant impact on earnings management of DMB'S in Nigeria during the period under study. Therefore, based on this evidence, the study fails to reject the null hypothesis two $\left(\mathrm{H}_{02}\right)$ which states that audit committee meeting has no significance effect on earnings management of listed deposit money banks in Nigeria.

Hypotheses 3: audit committee tenure has no significance effect on earnings management of listed deposit money banks in Nigeria

Similarly, the results from the table indicates that audit committee tenure (ACTE) has a negative and insignificant impact on FRQ of listed DMB'S in Nigeria, considering the coefficient of .00 and p-value of 0.32 . Thus, based on this statistical evidence, the study accepts the null hypothesis three $\left(\mathrm{H}_{03}\right)$ which states that audit committee tenure has no significance effect on earnings management of listed deposit money banks in Nigeria

Hypotheses 4: audit committee share ownership has no significance effect on earnings management of listed deposit money banks in Nigeria

Table 6 shows a positive and insignificant relationship between audit committee share ownership and FRQ of listed DMB'S in Nigeria, This is evident from the coefficient of .05 and a p-value of 0.16 . Based on this, the study therefore accepts the fourth null hypothesis $\left(\mathrm{H}_{04}\right)$ which states that audit committee share ownership has no significance effect on earnings management of listed deposit money banks in Nigeria

Hypotheses 5: audit committee busyness has no significance effect on earnings management of listed deposit money banks in Nigeria.

Also the table 6 shows that audit committee busyness has a significant negative impact on FRQ of listed deposit money banks in Nigeria as indicated by the coefficient of -..01 with P- value of 0.00 which is statistically significant at $1 \%$ level of significance. This means that audit committee busyness is significant in improving the earnings management of listed DMB's firms in Nigeria. Based on this, the study rejects the null hypotheses hypothesis five $\left(\mathrm{H}_{05}\right)$ which states that, audit committee busyness has no significance effect on earnings 
management of listed deposit money banks in Nigeria.

From the tests conducted on the data collected and the analyses of the results, this study found that audit committee characteristic is associated with earnings management of listed deposit money banks in Nigeria. The result from the study reveals that audit committee financial expertise (ACFEXP) in the listed DMB's in Nigeria has positive impact on the FRQ of the sampled firms. This signifies that any increase in the financial expertise of the members of the audit committee will increase the discretionary loan loss provision thereby improve the earnings management of the banks. This implies that audit committee financial expertise enhances the manner in which the audit committee evaluates the banks financial report. It also suggests that expertise knowledge by the audit committee members helps to detect misstatement and reduces earnings management. This finding is consistent with findings of prior studies such as Mangena and Pike 2005; Krishnan and Visvanathan 2008; Baxter and Cotter 2009; Lin and Hwang 2010, Kusnadi, Leong Suwardy, and Wang (2014), etc. who found audit committee financial expertise too positively and significantly improve earnings management. The study is also contrary to the work of Onyabe, Okpanachi, Nyor, Yahaya, and Ahmed (2018).

This study found that audit committee meeting has significant positive and insignificant impact on FRQ of listed DMB's in Nigeria. This is evidence from the coefficient of .00 and p-value of 0.29 from table 6 , this implies that an increase in the numbers of meeting held by the audit committee will have no impact on FRQ hence; earnings management is also not affected. This finding suggests that audit committee meeting does not influence management engagement earnings management practice in the sampled listed deposit money banks. This finding is in line with the work of Onyabe, Okpanachi, Nyor, Yahaya, and Ahmed (2018) who found audit committee meeting not to have influence on the quality of financial reporting. And it is also not consistent with the research work by Osarumwense and Aderemi (2016).

The study also found that audit committee tenure has a negative and insignificant impact on FRQ of DMB's in Nigeria. The table 4.4 above shows that ACTE has a coefficient of -.00 and p-value of 0.32 . This implies that whether there is an increase or decrease in audit committee tenure, the earnings management may not necessarily change either by increasing or decreasing. However, the finding collaborates with the view of Onyabe, Okpanachi, Nyor and Yahaya (2018) who state that audit committee tenure has not significant effect on earnings management. It also contradicts the findings of Adeyemi and Okpala (2011) and Okolie (2014) etc. who opinion that when the audit committee stay longer term, they may develop a close relationship with the management and impair independence which will eventually result in poor earnings management.

Table 6 shows that audit committee share ownership has a coefficient of .05 and p-value of 0.16 . This study found that audit committee share ownership has significant positive and insignificant impact on FRQ of listed DMB's in Nigeria. This implies that the percentage of share owns by the non-executive directors on the audit committee has no influence on the quality of their financial reporting of the banks. This implies that whether there is an increase or decrease in their shareholdings, the earnings management may not necessarily change either by increasing or decreasing.

The regression result from Table 6 also revealed that audit committee busyness has a t-value of -3.05 , a coefficient of -.01 and a p-value equal to 0.003 which is significant at $1 \%$. This means that audit committee meeting has a significant and a negative impact on discretionary loan loss provision. The coefficient of -.01 means that as members of the audit committee are holding more than one directorship, there will be a decline in discretionary loan loss provision thus, improving (increasing) the Earnings Management of the listed deposit money banks in Nigeria. This further means multiple directorship influence the earnings management positively. This could result from the experience the gather from other others board where they are directing. The result signifies that although they may be busy with others directorship the wealth of experience they bring from other directorship goes a long way in improving their monitoring skills and also improving the earnings management of the deposit money banks in Nigeria. The findings is in line with the study by (Fama \& Jenson, 1983; Shivdasani, 1993; Ferris et al., 2003; Carcello et al., 2002b; Bedard et al., 2004; Yang and Krishnan, 2005). They found a positive relationship and opinion that busy directors may be more able directors than their counterparts. It is also contrary to the study by Dhaliwal et al. (2010).

\section{Conclusion and Recommendations}

After careful review of the results and discussion, as well as relevant literatures, the study concludes that the audit committee financial expertise improves the earnings management of the DMB's in Nigeria. It is also concluded that the numbers of meeting held by the audit committee members does not influence the earnings management of the banks. Further, it is concluded that the longer the tenure of the audit committee the does not have impact on the earnings management of the listed deposit money banks in Nigeria. The study also concludes that an increase or decrease in audit share ownership of listed Nigeria does not affect their earnings management deposit money banks in Nigeria. Finally the study concludes that audit committee busyness enhances the quality of financial report of the deposit money banks in Nigeria.

In line with the findings and the conclusion of this study, the following recommendations made. 
i) The board of directors of deposit money banks should be more inclined in engaging the services of members with financial expertise. This is because such committee member will be able to select and implement audit procedures that are precise and effective when delivering their service.

ii) Further for more reliability of financial report, the study recommends that supervisory boards and regulators should encourage more inclusion of financial expertise members in the audit committee.

iii) The study also recommends the inclusion of more directors with multiple directors on the audit committee as their wealth of experience helps reducing earnings management thus improving the earnings management of the banks.

Further research may be needed to be conducted on the audit committee attributes in other sectors other than deposit money banks like industrial goods companies.

\section{References}

Abbott, L. J., Parker, S., \& Peters, G. F. (2004). Audit committee characteristics and restatements. Auditing: A Journal of Practice \& Theory, 23, 69-87.

Adeyemo K. A., Eriebie S. O., Adetiloye K., \& Ben-Caleb E. (2015). Audit Committee Attributes and Financial Reporting Quality in Nigerian Quoted Companies. International Business Management 10 (22), 5326-5335

Adeyemi, S. B., \& Fagbemi, T. O. (2011). The perception of ethics in auditing profession in Nigeria. Journal Accounting and Taxation, 3(7), 146.

Bala, H., \& Gugong, B. K. (2015). Audit committee characteristics and earnings quality of listed food and beverages firms in Nigeria. International Journal of Accounting, Auditing and Taxation, 2(8), 1-13.

Barth, M., Landsman, W., \& Lang, M. (2008). International Accounting Standards and Accounting Quality. Journal of Accounting Research, 46(3), 467-498.

Baxter, P., \& Cotter, J. (2009). Audit committees and earnings quality. Accounting and Finance, 49, $267-290$.

Beasley, M.S. (1996). Board of director composition and financial statement fraud. The Accounting Review, 71, 443-465.

Bedard, J., Chtourou, S. M., \& Courteau, L. (2004). The effect of audit committee expertise, independence, and activity on aggressive earnings management. Auditing: A Journal of Practice \& Theory, 23, 13-35.

Boone, J. P., Khurana I. K., \& Raman K. K. (2008). Audit firm tenure and the equity risk premium. Journal of Accounting, Auditing and Finance, 23, 125-140.

Bushman, R. M., \& Piotroski, J. D. (2006). Financial reporting incentives for conservative accounting: The influence of legal and political institutions. Journal of Accounting and Economics, 42 (1), 107-148.

Carcello, J. V., Hermanson, D., Neal, T. \& Riley, R. (2002b). Board characteristics and audit fees. Contemporary Accounting Research, 19, 365-384.

Carcello, J. V., \& Neal, T. (2003a). Audit committee characteristics and auditor dismissals following "new" goingconcern reports. The Accounting Review, 78, 95- 117.

Companies and Allied Matters Act (CAMA) (2004) Lagos: Federal Government printer.

Davidson III, W. N., B. Xie, \& W. Xu. (2004). Market reaction to voluntary announcements of audit committee appointments: The effect of financial expertise. Journal of Accounting and Public Policy, 23 (4):279-293.

DeFond, M. L., \& Francis, J. R. (2005). Audit research after Sarbanes-Oxley. Auditing: A Journal of Practice \& Theory, 24, 5-30.

Dhaliwal, D., Naiker, V., \& Navissi, S. (2010). The association between accruals quality and the characteristics of accounting experts and mix of expertise on audit committees. Contemporary Accounting Research, 27, 787827.

Eriabie, S. O. (2016). Impact Of Audit Committee Attributes On Financial Reporting Quality In Nigerian Quoted Companies. ICAN Journal of Accounting \& Finance, 5(1), 117-137.

Fama, E.F., \& Jensen, M. C. (1983). Separation of ownership and control. Journal of Law and Economics, 26, 301-325

Ferris, S. P., Jagannathan, M., \& Pritchard, A.C (2003). Too busy to mind the business? Monitoring by directors with multiple board appointments, Journal of Finance, 58, 1087-1111.

Fich, E. M., \& Shivdasani, A. (2006). Are busy boards effective monitors? The Journal of Finance, 56, 689 - 724.

Forker, J. J. (1992). Corporate governance and disclosure quality. Accounting and Business research, 22(86), 111124.

IASB. (2008). Exposure Draft on an improved Conceptual Framework for Financial Reporting, IASB.

Jensen, M. C. (1993). The modern industrial revolution, exit, and the failure of internal control systems. The Journal of Finance, 48(3), 831-880.

Kalbers, L., \& Fogarty, T. (1993). Audit committee effectiveness: An empirical investigation of the contribution of power. Auditing: A Journal of Practice and Theory, 12, 24 - 49.

Klein, A. (2002b). Economic determinants of audit committee independence. The Accounting Review, 77, 435452. 
Knapp, M. C. (1987). An empirical study of audit committee support for auditors involved in technical disputes with client management. The Accounting Review, 62, 578-588.

Krishnan, G. V. \& Visvanathan, G. (2008). Does the SOX definition of an accounting expert matter? The association between audit committee directors' accounting expertise and accounting conservatism. Contemporary Accounting Research, 25, 827-857.

Kusnadi, Y., Leong, K. S., Suwardy, T., \& Wang, J.(2014). Audit Committees and Financial Reporting Quality in Singapore. Journal of Business Ethics, Forthcoming; Singapore Management University School of Accountancy Research.

Available SSRN: https://ssrn.com/abstract=2467456 or http://dx.doi.org/10.2139/ssrn.2467456

Lavelle, L. (2002). Enron: How governance rules failed, Business Week, Issue 3766, pp. 28-29.

$\mathrm{Li}, \mathrm{S}$. (2010). Does mandatory adoption of International Financial Reporting Standards in the European Union reduce the cost of equity capital? The accounting review, 85(2), 607-636.

Lin, J. W., \& Hwang, M. I. (2010). Audit quality, corporate governance, and earnings management: a metaanalysis. International Journal of Auditing, 14, 57-77.

Madawaki, A., \& Amran, N. A. (2017). Audit Committee Characteristics and Financial Reporting Quality: Evidence from Nigerian Listed Companies. Terengganu International Finance and Economics Journal (TIFEJ), 3(1), 30-37.

Mangena, M. \& Pike, R. (2005). The effect of audit committee shareholding, financial expertise and size on interim financial disclosures. Accounting and Business Research, 35, 327-349.

Okolie, A. O. (2014). Auditor tenure, auditor independence and accrual-based earnings management of quoted companies in Nigeria. European Journal of Accounting Auditing and Finance Research, 2(2), 63-90.

Onyabe, J. M., Okpanachi, J., Nyor, T., Yahaya, O. A., \& Ahmed, M. (2018). Effect of Audit Committee Tenure on Financial Reporting Quality of Listed Deposit Money Banks in Nigeria. European Scientific Journal, ESJ, 14(4).

Osarumwense, E. S., \& Aderemi, A. K. (2016). The Impact of Financial Literacy and Frequency of Meetings of Members of Audit Committe on Financial Reporting Quality in Nigerian Quoted Companies. About this journal, 1.

O'Sullivan, N. (2005). Why do executives serve as non-executives? Pre-Cadbury evidence from UK non-financial companies. Accounting and Business Research, 35, 161-176.

O'Sullivan, N. (2009, June). The impact of directors' and officers' insurance on audit pricing: Evidence from UK companies. In Accounting Forum (Vol. 33, No. 2, 146-161). Elsevier.

Page, M. \& Spira, L. (2005). Ethics, independence and the conservation of ambiguity. Business Ethics: A European Review, 14, 301-316.

Ruzaidah, R., \& M. Takiah. (2004). The effectiveness of audit committee in monitoring the quality of corporate governance. Corporate Governance: An International Perspective, Malaysian Institute of Corporate Governance, Kuala Lumpur, 154-175.

Srinivasan, S. (2005). Consequences of financial reporting failure for outside directors: evidence from accounting restatements and audit committee members. Journal of Accounting Research, 43, 291-334.

Stewart, J. \& Munro, L. (2007). The impact of audit committee existence and audit committee meeting frequency on the external audit: perceptions of Australian auditors. International Journal of Auditing, 11, 51-69.

Sylvester, O. A. \& Edith, E. O. (2016). Corporate Financial Reporting: Adopting the International Financial Reporting Standard in Nigeria Firms. Journal of Policy and Development Studies, 289(3519), 1-11.

Umobung, A. A., \& Ibanichuka, E. A. L. (2017). Audit Committee Attributes and Financial Reporting Quality of Food and Beverage Firms in Nigeria, International Journal of Innovative Social Sciences \& Humanities Research 5(2):1-13

Vafeas, N. (2005). Audit committees, boards, and the quality of reported earnings. Contemporary Accounting Research, 22, 1093-1122.

Van Beest, F., Braam, G., \& Boelens, S. (2009). Quality of Financial Reporting: measuring qualitative characteristics. Nijmegen Center for Economics (NiCE). Working Paper, 09-108.

Yang, J. S. \& Krishnan, J. (2005). Audit committees and quarterly earnings management. International Journal of Auditing, 9, 201-219. 